http://dx.doi.org/10.18778/1509-877X.2018.02.05

\title{
ZASADA KUMULACJI W PODATKU OD SPADKÓW I DAROWIZN - STRUKTURA GEĘBOKA KONTRA GRANICA JĘZYKOWA WYKŁADNI
}

Streszczenie. Zasada kumulacji w podatku od spadków i darowizn jest, jako koncepcja prawna, instytucją o stuletniej historii. Ze względu na zmiany o charakterze legislacyjno-systemowym interpretacja przepisów ustanawiających jej byt prawny napotyka na duże trudności. Traktowanie granicy wykładni językowej bezwzględnie prowadzi do niemożliwego do zaakceptowania rezultatu. Rozwiązaniem zapewniającym prawidłowe funkcjonowanie zasady kumulacji jest wykroczenie poza granicę językową wykładni, tak by wynik wykładni pozostawał w zgodzie z głęboką strukturą ustawy podatkowej. W przełamaniu granicy językowej może pomóc metoda wykładni prawa uwzględniająca problem kontekstualizmu oraz koherencję prawa i struktury prawno-ekonomiczne związane z ustawą podatkową.

Słowa kluczowe: zasada kumulacji, granica językowa, wykładnia prawa podatkowego, podatek od spadków i darowizn, koherencja, struktura głęboka

Artykuł 9 ust. 2 Ustawy z dnia 28 lipca 1983 r. o podatku od spadków i darowizn ${ }^{1}$ (dalej: u.p.s.d.) wyraża zasadę kumulacji (zwanej również kumulacją przedmiotowo-podmiotową), stanowiąc, że gdy nabycie własności

* Adiunkt na Wydziale Prawa i Ekonomii, Uniwersytet Humanistyczno-Przyrodniczy im. Jana Długosza w Częstochowie, doradca podatkowy, nr wpisu 11484, e-mail: a.slysz@ujd.edu.pl

1 Tekst jedn. Dz.U. z 2018 r., poz. 644. 
rzeczy i praw majątkowych od tej samej osoby następuje więcej niż jeden raz, do wartości rzeczy i praw majątkowych ostatnio nabytych dolicza się wartość rzeczy i praw majątkowych nabytych od tej osoby lub po tej samej osobie w okresie 5 lat poprzedzających rok, w którym nastąpiło ostatnie nabycie. Ten sam przepis w swej treści stanowi także, że od podatku obliczonego od łącznej wartości nabytych rzeczy i praw majątkowych potrąca się podatek przypadający od opodatkowanych poprzednio nabytych rzeczy i praw majątkowych².

Przywołana regulacja ma długą jak na instytucję prawa podatkowego historię legislacyjną. Zasadę kumulacji zawierała, również w art. 9 ust. 2, Ustawa z dnia 19 grudnia 1975 r. o podatku od spadków i darowizn³. Przepis ten poprzedzał zaś art. 14 ust. 1 Dekretu (z mocą ustawy) z dnia 3 lutego 1947 r. o podatku od nabycia praw majątkowych ${ }^{4}$. Przepis ten nakazywał, dla okresu 6 lat, jeżeli nieodpłatne nabycie prawa majątkowego od tej samej osoby nastąpiło kilkakrotnie, doliczać do wartości ostatniego prawa majątkowego wartość praw majątkowych poprzednio nabytych. Kumulacyjne podejście do podstawy opodatkowania w przypadku nabycia wielokrotnego od tej samej osoby występowało w prawie polskim znacznie wcześniej. Już przed II wojną światową norma regulująca zakres kumulacji została osadzona w art. 14 Rozporządzenia Ministra Skarbu z dnia 4 maja 1923 r. ${ }^{5} \mathrm{w}$ przedmiocie jednolitego tekstu przepisów ustawowych o opodatkowaniu spadków i darowizn na obszarze byłej dzielnicy rosyjskiej. Dla większości terytorium kraju po odzyskaniu niepodległości zasada kumulacji została powołana do życia za sprawą jeszcze starszego aktu prawnego, a mianowicie Ustawy z dnia 29 maja 1920 r. w przedmiocie zmiany przepisów o opodatkowaniu spadków i darowizn ${ }^{6}$. W tymże akcie prawnym postanowiono, że obowiązywać będą na całym obszarze Rzeczypospolitej przepisy artykułów od 2 do 24 tejże ustawy. Pośród tych przepisów znajdował się art. 7 stanowiący, że w sytuacji, gdy ten sam darujący z tym samym obdarowanym zawarli dwie lub więcej umów podlegających podatkowi od darowizn, „natenczas podatek od każdej z tych umów wymierza się według stopy jednolitej, odpowiadającej sumie podstaw wymiaru, obliczonych co do każdej umowy z osobna”. W tym samym

${ }^{2}$ Nadwyżka podatku, która ewentualnie wynika z obliczenia, nie podlega jednak zaliczeniu na poczet innych podatków ani zwrotowi, a nabywcy obowiązani są w zeznaniu podatkowym wymienić rzeczy i prawa majątkowe nabyte w podanym wyżej okresie.

3 Dz.U. z 1975 r., Nr 45, poz. 228 ze zm.

4 Dz.U. z 1947 r., Nr 27, poz. 106.

5 Tekst jedn. Dz.U. z 1923 r., Nr 55, poz. 391 ze zm.

${ }^{6}$ Dz.U. z 1920 r., Nr 49, poz. 299 ze zm. 
artykule międzywojenny ustawodawca wskazał, że powyższa zasada znajduje zastosowanie odpowiednio, jeżeli ktoś nabył majątek w sposób uzasadniający wymiar podatku spadkowego, a nadto zawarł ze spadkodawcą jedną lub więcej umów podlegających podatkowi od darowizn.

Zasada kumulacji przedmiotowo-podmiotowej nie jest rozwiązaniem nowym w krajowym porządku prawnym, jej niemal stuletnia historia związana jest $\mathrm{z}$ uniemożliwieniem podatnikom unikania opodatkowania ${ }^{7}$ poprzez dokonywanie wielu darowizn w miejsce jednej, o podstawach opodatkowania mniejszych od kwoty wolnej od podatku lub o niższej kwocie nadwyżki podstawy opodatkowania ponad kwotę wolną od podatku (co pozwalałoby na opodatkowanie niższą stawką). Do chwili wejścia w życie w dniu 1 stycznia 2007 r. art. 4a u.p.s.d. praktyka stosowania mechanizmu kumulacji nie budziła większych wątpliwości, a te, które się pojawiały, koncentrowały się wokół problemu ustalenia zakresu pojęcia „podatek przypadający”. Działanie mechanizmu kumulacji sprowadza się więc zasadniczo do tego, że gdy dokonane zostaną (między tymi samymi osobami z II grupy podatkowej ${ }^{8}$, np. w tym samym miesiącu) trzy darowizny o wartości 7000 zł, każda podlegać będzie łącznemu opodatkowaniu, mimo że wartość poszczególnych darowizn jest mniejsza niż kwota wolna od podatku, albowiem ich suma przekracza tę kwotę, tj. 7276 zł. Ze względu na konieczność zastosowania zasady kumulacji, by obliczyć podstawę opodatkowania, od sumy darowizn (a precyzyjniej, od wartości ostatnio nabytej darowizny z doliczonymi wartościami darowizn nabytych od tej samej osoby w okresie 5 lat poprzedzających rok, w którym nastąpiło ostatnie nabycie), tj. kwoty 21000 zł, odjąć należy kwotę wolną 7276 zł. Tym samym opodatkowaniu rzeczywiście będzie podlegać wartość 13724 zł.

7 Pojęciem unikania opodatkowania posługuję się w znaczeniu podejmowania przez podatnika działań prawem dozwolonych w celu wyeliminowania bądź zmniejszenia ciężaru podatkowego; por. np. M. Kurzac, Unikanie opodatkowania a uchylanie się od opodatkowania, „Studia Prawno-Ekonomiczne” 2017, t. 105, s. 11-22, cejsh.icm.edu.pl/cejsh/ element/bwmeta1.element.desklight-b23d0373-f073-4e09-9926-b2e8c8c1a611/c/01_ Kurzac.pdf (dostęp: 3.03.2018).

${ }^{8}$ Do podatkowej II grupy w podatku od spadków i darowizn zalicza się zstępnych rodzeństwa, rodzeństwo rodziców, zstępnych i małżonków pasierbów, małżonków rodzeństwa i rodzeństwo małżonków, małżonków rodzeństwa małżonków, małżonków innych zstępnych. 
Jednakże w przypadku, gdyby poprzednie nabycia podlegały opodatkowaniu od podatku obliczonego od łącznej wartości nabyć, należałoby potrącić „podatek przypadający” od opodatkowanych poprzednio nabyć.

Powołany do życia z dniem 1 stycznia 2016 r. art. 6 ust. 1a u.p.s.d. wzmacnia rolę omawianej regulacji; przepis ten stanowi, że jeżeli nabycie następuje w częściach, obowiązek podatkowy powstaje $\mathrm{z}$ chwilą nabycia poszczególnych części. Tak jasne i wprost wyrażone w tekście ustawy sformułowanie przecina istniejące do tego momentu wątpliwości, czy powstanie obowiązku podatkowego wymaga spełnienia świadczenia podlegającego opodatkowania w całości, czy też wystarczy, że dojdzie do jego spełnienia w części. Problemy interpretacyjne w tym zakresie zostały rozpoznane przez Naczelny Sąd Administracyjny (NSA) w Warszawie w sprawie zakończonej wyrokiem z dnia 17 maja 2016 r. ${ }^{10}$ Sąd uznał, że w stanie prawnym obowiązującym do dnia 31 grudnia 2015 r. obowiązek podatkowy nie powstawał w stosunku do poszczególnych części świadczenia darowizny, gdy darowizna ta świadczona była $\mathrm{w}$ ratach. $\mathrm{Z}$ tezą orzeczenia należy się zgodzić. Trzeba jednak zauważyć, w odniesieniu do stanu prawnego sprzed 1 stycznia 2016 r., że w praktyce niejednokrotnie trudno będzie organom podatkowym, które zidentyfikują otrzymanie kilku darowizn pieniężnych (wykonanych pomiędzy tymi samymi osobami), ustalić, czy miejsce miało kilka samodzielnych darowizn czy też jedna, ale wypłacana w ratach. Znaczenie tego zagadnienia uwidacznia się już w sytuacji, gdy konieczne jest ustalenie, czy należy/należało złożyć, w przypadku darowizn spełniających pozostałe warunki zwolnienia przewidzianego $w$ art. 4a u.p.s.d., jedno zgłoszenie SD-Z2 i objąć nim wszystkie części darowizny, czy też zgłoszeń winno być tyle, ile części, tj. rat darowizny. Konsekwencją powyższego jest powstanie kolejnego problemu, od kiedy należało liczyć termin na złożenie zgłoszenia? Z dniem 1 stycznia 2016 r. jasne się stało, że obecnie już spełnienie części większego świadczenia prowadzi do powstania obowiązku podatkowego. Konsekwencją opisanej zmiany u.p.s.d. o charakterze normatywnym jest wzmocnienie roli i częstotliwości stosowania art. 9 ust. 2 u.p.s.d.

Należy zauważyć, że okres 5 lat, o którym mowa w art. 9 ust. 2 u.p.s.d., należy liczyć od 1 stycznia roku, który o 5 lat poprzedza rok, w którym

9 Artykuł 9 ust. 2 Ustawy z dnia 28 lipca 1983 r. o podatku od spadków i darowizn (tekst jedn. Dz.U. z 2018 r., poz. 644).

${ }_{10}$ Wyrok NSA w Warszawie z dnia 17 maja 2016 r., sygn. II FSK 941/14, LEX/el. nr 2083025. 
nastąpiło ostatnie nabycie ${ }^{11}$. W praktyce zatem okres objęty kumulacją faktycznie wydłuża się niemal do sześciu lat ${ }^{12}$. Analizowany przepis stanowi, że kumulacja obejmuje okres „,5 lat poprzedzających rok, w którym nastąpiło ostatnie nabycie”. Mogą się więc pojawić pewne wątpliwości na gruncie wykładni językowej, czy kumulacja obejmuje nabycia z roku, w którym nastąpiło ostatnie nabycie. Jeśli mielibyśmy do czynienia $\mathrm{z}$ darowizną wykonaną w czerwcu 2018 r., którą poprzedzają darowizny z marca 2018 r. oraz maja 2017 r. i grudnia 2016 r., to za nabycia mające miejsce w okresie 5 lat poprzedzających rok 2018, czyli ten, w którym nastąpiło ostatnie nabycie, należałoby uznać jedynie darowizny z maja 2017 r. i grudnia 2016 r., a darowiznę z marca 2018 r. już nie. Taka wykładnia przeczyłaby celowi istnienia zasady kumulacji. Niemniej jednak okres „,5 lat poprzedzających rok, w którym nastąpiło ostatnie nabycie" to co innego niż np. okres od 1 stycznia roku, który o pięć lat poprzedza rok, w którym nastąpiło ostatnie nabycie, do dnia ostatniego nabycia włącznie. Jeśli ostatnie nabycie ma miejsce w czerwcu 2018 r., to językowa wykładnia nakazuje uznać, że ów okres 5 lat poprzedzających rok, w którym nastąpiło ostatnie nabycie, obejmuje okres od 1 stycznia 2013 r. do 31 grudnia 2017 r. W taki jednak sposób doszłoby do pominięcia okresu od 1 stycznia 2018 r. do dnia ostatniego nabycia w czerwcu 2018 r.

Wyrażona w art. 9 ust. 2 u.p.s.d. zasada kumulacji skrywa w swej treści również inny problem, jak się wydaje - znacznie bardziej kłopotliwy dla podatników niż przedstawiony w poprzednim akapicie, albowiem prowadzić może do wzrostu zobowiązania podatkowego. Zagadnienie to ma swe źródło w konstrukcji kumulacji podstawy opodatkowania, a dokładniej - w przesłankach kwalifikujących pod działanie mechanizmu doliczania wartość rzeczy i praw majątkowych nabytych uprzednio, tj. przed ostatnim nabyciem. Doliczenie, o którym mowa w art. 9 ust. 2 u.p.s.d., obejmuje wszelkie wartości nabyte, nie tylko te, których nabycie spowodowało wcześniej powstanie zobowiązania podatkowego. W sytuacji, gdy nabycie następuje w częściach, obowiązek podatkowy powstaje z chwilą nabycia każdej części, co w połączeniu z możliwością odtrącenia jedynie podatku przypadającego może spowodować, iż w szerokim

${ }_{11}$ K. Chustecka, I. Krawczyk, M. Kurasz, Art. 9, [w:] K. Chustecka, I. Krawczyk, M. Kurasz, Ustawa o podatku od spadków i darowizn. Komentarz, LEX/el. 2007.

12 J. Serwacki, Art. 9, [w:] idem, Ustawa o podatku od spadków i darowizn. Komentarz, LEX/el. 2001. 
spektrum stanów faktycznych dojdzie do nieoczekiwanego pogorszenia sytuacji podatników.

Należy wyjaśnić, że użyte przez ustawodawcę pojęcie „podatku przypadającego" nie jest tożsame swym zakresem z pojęciem podatku zapłaconego. Jak wyjaśnił Naczelny Sąd Administracyjny w Warszawie w wyroku z dnia 2 września 2015 r. $^{13}$, zasada kumulacji nakazuje potrącić (by nie dochodziło do sytuacji, w której od jednej czynności prawnej następowałoby dwukrotne wymierzenie podatku) „od podatku obliczonego od łącznej wartości nabytych rzeczy i praw majątkowych w okresie 5 lat poprzedzających rok, w którym nastąpiło ostatnie nabycie, także podatek przypadający (a więc nie tylko zapłacony) od opodatkowanych poprzednio nabytych rzeczy i praw majątkowych także wtedy, gdy zasadą kumulacji obejmuje się nabycie wcześniejsze niż z ostatniego roku obejmującego okres 5 lat, o ile jedno choćby z tych nabyć objęte było obydwiema kumulacjami”. Innymi słowy, „potrąceniu od podatku od nabycia późniejszego podlega podatek od nabycia poprzedniego"14. Pomniejszenie będzie więc mogło zostać dokonane także w sytuacji, gdy podatek nie został zapłacony, nawet jeżeli zobowiązanie podatkowe nie wygasło wskutek np. przedawnienia. Pojęcie podatku przypadającego obejmuje zatem również zaległość podatkową. Nie można zapominać, że ów podatek przypadający musi według ustawodawcy przypadać od opodatkowanych poprzednio nabytych rzeczy i praw majątkowych, nie wystarczy więc samo podleganie opodatkowaniu ze zwolnieniem, by uznać, że doszło do pojawienia się podatku przypadającego, który można by potrącić od podatku obliczonego od łącznej wartości nabytych rzeczy i praw majątkowych.

\section{KuMULACJA PRZEDMIOTOWO-PODMIOTOWA W DZIAŁANIU}

Realizując proces wykładni w sposób klasyczny dla prawa podatkowego (czyli przyjmując prymat wykładni językowej ${ }^{15}$ ) i godząc się z istnieniem granicy językowej wykładni (niezależnie od tego, czy uznamy, że jest nią możliwe językowe znaczenie art. 9 ust. 2 u.p.s.d., czy też podejdziemy do istnienia granicy przez pryzmat złożonej koncepcji modelu analitycznego

13 Wyroki NSA: z dnia 2 września 2015 r., sygn. II FSK 1952/13, LEX/el. nr 1795643, oraz z dnia 2 września 2015 r., sygn. II FSK 1951/13, LEX/el. nr 1780971.

14 Wyrok NSA z dnia 14 lutego 2018 r., sygn. II FSK 1950/13, LEX/el. nr 2480789.

15 Zob. B. Brzeziński, Wykładnia prawa podatkowego, Gdańsk 2013, s. 23-63. 
lub dekonstrukcyjnego ${ }^{16}$, czy w jeszcze inny znany nauce prawa sposób), otrzymany rezultaty wykładni art. 9 ust. 2 u.p.s.d. prowadzi w razie jego zastosowania (dla konkretnego stanu faktycznego) do sytuacji absurdalnej z punktu widzenia konstrukcji podatku od spadków i darowizn.

Najłatwiej zobrazować wadliwe i niemożliwe do przyjęcia działanie mechanizmu kumulacji przedmiotowo-podmiotowej, skonstruowanego z poszanowaniem językowej granicy wykładni, na następującym przykładzie:

- w dniu 1 grudnia 2017 r. syn otrzymał od ojca darowiznę (przelew na rachunek bankowy) pieniężną 1000000 zł;

- spełnione zostały wszystkie przesłanki zwolnienia z art. 4a u.p.s.d.;

- w dniu 1 lutego 2018 r. syn otrzymał od ojca drugą darowiznę (przelew na rachunek bankowy) tym razem w wysokości $200000 \mathrm{zl}$;

- obdarowany nie złożył SD-Z2 od drugiego z nabyć w terminie 6 miesięcy, co powoduje, że nabycie podlega opodatkowaniu na zasadach określonych dla nabywców zaliczonych do I grupy podatkowej zgodnie $\mathrm{z}$ art. 4a ust. 3 u.p.s.d., tym samym obdarowany ma prawo uwzględnienia kwoty wolnej od podatku w wysokości 9637 zł.

Dla tak opisanego stanu faktycznego, zgodnie z otrzymanym wynikiem wykładni językowej, który determinuje sposób stosowania kumulacji przedmiotowo-podmiotowej, obliczając kwotę zobowiązania podatkowego i wcześniej ustalając podstawę opodatkowania, pod uwagę trzeba wziąć obie darowizny. Jednakże nie pojawia się tu możliwość odliczenia podatku przypadającego od pierwszej darowizny, ten bowiem w ogóle się nie zrodził, co prowadzi do nadmiernego opodatkowania, które uwidacznia przykład zamieszczony poniżej.

4. Praktyczne zastosowanie (W modelu uproszczonym) ZASADY KUMULACJI

$1000000 \mathrm{zł}$ (wartości nabyte w okresie 5 lat poprzedzających rok, w którym nastąpiło ostatnie nabycie) + $200000 \mathrm{zł}$ (nabyta ostatnio wartość) = 1200000 zł (łączna wartość nabytych rzeczy i praw majątkowych);

1200000 zł (łączna wartość nabytych rzeczy i praw majątkowych) - 0 zł (podatek przypadający od opodatkowanych poprzednio nabytych rzeczy i praw majątkowych) = $1200000 \mathrm{zł}$;

16 T. Spyra, Granice wykładni prawa. Znaczenie językowe tekstu prawnego jako granice wykładni, Kraków 2006, s. 109 i n. 
$1200000 \mathrm{zł}-9637$ zł (kwota wolna) = 1190363 zł (podstawa opodatkowania);

1190363 zł - 20566 (nadwyżka podstawy opodatkowania ponad kwotę wolną od podatku opodatkowana podatkiem w wysokości 822,30 zł) = $1169797 \mathrm{zl}$;

obliczenie podatku: 7\% z 1169797 zł (czyli z nadwyżki ponad 20556 zł) + $822,20 \mathrm{zl}=\mathbf{8 2} \mathbf{7 0 7 , 9 9} \mathbf{z l}$ (do zaokrąglenia).

Wariacja I

By zobrazować dokładniej absurd stosowania zasady kumulacji w zgodzie z wykładnią językową, należy porównać przedstawiony stan faktyczny z sytuacją, w której przelew środków pieniężnych na kwotę 200000 zł stanowiłby jedyną darowiznę. W takiej sytuacji opodatkowanie - w pewnym uproszczeniu - prezentowałoby się w sposób następujący:

$200000 \mathrm{zł}$ (nabyta wartość) - $9637 \mathrm{zł}($ kwota wolna $)=190363 \mathrm{zł}($ podstawa opodatkowania);

190363 zł - 20566 zł (nadwyżka podstawy opodatkowania ponad kwotę wolną od podatku opodatkowana podatkiem w wysokości 822,30 zł) = $169807 \mathrm{zł}$ (podstawa opodatkowania stawką 7\%);

obliczenie podatku: 7\% z 169807 zł (czyli z nadwyżki ponad 20556 zł) + $822,20 \mathrm{zl}=12$ 708,69 zl (do zaokrąglenia).

Widać więc wyraźnie, że uwzględnienie w podstawie opodatkowania zwolnionej z opodatkowania darowizny zwiększa podatek z 12 708,69 zł do 82 707,99 zł (przed zaokrągleniem).

Wariacja II

W niektórych sytuacjach podatek może przewyższać nabytą wartość. Stosując kumulację przedmiotowo-podmiotową, gdy pierwsza (zwolniona) darowizna to $1000000 \mathrm{zł}$ i gdy przyjmiemy, że druga darowizna ma wartość 10000 zł i nie korzysta ze zwolnienia z art. 4a ust. 1 u.p.s.d., mamy do czynieni z następującą sytuacją:

1000000 zł (wartości nabyte w okresie 5 lat poprzedzających rok, w którym nastąpiło ostatnie nabycie) + $10000 \mathrm{zł}$ (nabyta ostatnio wartość) = $1010000 \mathrm{zł}$ (łączna wartość nabytych rzeczy i praw majątkowych);

1010000 zł (łączna wartość nabytych rzeczy i praw majątkowych) - 0 zł (podatek przypadający od opodatkowanych poprzednio nabytych rzeczy i praw majątkowych) = $1010000 \mathrm{zł;}$ 
$1010000 \mathrm{zl}-9637$ zł (kwota wolna) = $1000363 \mathrm{zł}$ (podstawa opodatkowania);

$1010000 \mathrm{zł}$ - $20566 \mathrm{zł}$ (nadwyżka podstawy opodatkowania ponad kwotę wolną od podatku opodatkowana podatkiem w wysokości 822,30 zł) = $979797 \mathrm{zk}$;

obliczenie podatku: 7\% z 979797 zł (czyli z nadwyżki ponad 20556 zł) $+822,20 \mathrm{zl}=\mathbf{6 8} 585,79 \mathrm{zl}$ (do zaokrąglenia).

W sytuacji przedstawionej w wariacji II nabycie w drodze darowizny np. środków pieniężnych w kwocie 10000 zł powoduje, gdy wcześniej nabyto, korzystając ze zwolnienia 1000000 zł, powstanie zobowiązania podatkowego wielokrotnie wyższego (6,8 raza) niż wartość otrzymanej darowizny. Trudno zaakceptować taką sytuację, ale jest ona wynikiem faktu, że granica językowa, jaką buduje tu klasyczna wykładnia, zmusza do zaliczenia do skumulowanej podstawy opodatkowania darowizny zwolnionej od podatku na mocy art. 4a u.p.s.d. i pozwala na potrącenie jedynie podatku przypadającego od opodatkowanych poprzednio nabytych rzeczy i praw majątkowych.

\section{JęZYKOWA GRANICA WYKŁADNI}

Przywołane przykłady dowodzą, że istnieje w analizowanej sytuacji niezgodność wyniku wykładni językowej (czy też dokładniej - wykładni derywacyjnej respektującej istnienie granicy językowej) z sensem i duchem struktury podatku od spadków i darowizn; jednocześnie jasne jest, że wykładnia zgodna z sensem i duchem struktury podatku musiałaby bazować na jego strukturze i przekraczałaby w konsekwencji granicę językową wykładni.

Nauka nie jest zgodna, co należy zrobić w takiej sytuacji. W niektórych wyrokach Naczelnego Sądu Administracyjnego stawano na stanowisku, że nie należy wykraczać w drodze wykładni poza granice zawarte w ramach możliwego sensu słów zawartych w tekście prawnym, gdyż wykładnia, która jest sprzeczna z tym sensem, nie powinna być dokonywana w państwie prawnym ${ }^{17}$. Nie tylko część orzecznictwa stoi na takim stanowisku, również niektórzy przedstawiciele nauki uznają, że wykładnia językowa „zakreśla granice interpretacji prawa podatkowego w ramach

17 Wyrok NSA z dnia 6 maja 2015 r., sygn. I GSK 1415/13, LEX/el. nr 1773015. 
możliwego sensu słów zawartych w jego przepisach"18. Z drugiej strony od lat wskazuje się, że gdy rezultaty wykładni językowej są absurdalne, powinno dojść do przełamania znaczenia językowego ${ }^{19}$, oraz że możliwe jest odejście od rezultatów wykładni językowej, także gdy jej rezultat stoi w zasadniczej sprzeczności z hierarchią wartości interpretatora ${ }^{20}$. Aktualne jest zatem pytanie, na ile można poprawić prawodawcę, gdy językowa granica wykładni wymaga złamania w celu ochrony pewnych ogólnych regu $^{21}$. Od wielu lat wskazuje się, że wykładnia językowa prawa podatkowego powinna kierować się specyficznymi cechami, wynikającymi z istoty prawa podatkowego ${ }^{22}$, ale czy istota prawa podatkowego uzasadniać może przełamanie bariery językowej w celu postąpienia słusznego i zgodnego ze strukturą podatku?

Jeśli odpowiemy twierdząco na ostatnie z postawionych pytań i uznamy, że w wyjątkowych sytuacjach należy przełamać barierę językową, konieczne jest oparcie wyniku wykładni na solidnych podstawach. W trakcie procesu wykładni art. 9 ust. 2 u.p.s.d. ujawnia się problem statyki i dynamiki wykładni celowościowej (inny bowiem był stan prawny przy wprowadzaniu przepisu, a inny jest obecnie, co powoduje jego wadliwe działanie), ponadto derywację normy z przepisu utrudnia również zmieniający się kontekst systemowy, co jest szczególnie widoczne, gdy spojrzymy na moment pojawienia się normy w krajowym porządku prawnym. Ponadto wyraźna granica językowa koliduje z całością unormowań ustawy, gdyż przepisy analizowane kompleksowo ujawniają istnienie modelu legislacyjno-ekonomiczno-finansowego podatku od spadków i darowizn, z którego przemawia racjonalność i koherentność struktury. Jak wynika $\mathrm{z}$ powyższego, w procesie wykładni art. 9 ust. 2 u.p.s.d. konieczne jest rozwiązanie wielu nadzwyczajnych problemów i dopiero gdy zostaną one rozwiązane, dojdzie do pojawienia się fundamentów pod ostateczne wyniki wykładni.

18 R. Mastalski, Miejsce wykładni językowej w procesie stosowania prawa podatkowego, „Przegląd Podatkowy” 2007, nr 8, s. 12.

19 H. Filipczyk, Postulat pewności prawa w wykładni operatywnej prawa podatkowego, Warszawa 2013, s. 88.

20 Zob. B. Brzeziński, Wykładnia..., s. 25.

21 A. Kotowski, Językowa granica wykładni a reguła słuszności. Glosa do postanowienia SN z dnia 2 lutego 2012 r. (IV KK 273/11), „Przegląd Sądowy” 2010, nr 10, s. 120-127.

22 R. Mastalski, Wykładnia językowa $w$ interpretacji prawa podatkowego, „Przegląd Podatkowy" 1999, nr 8, s. 3. 
Zasadniczo proces i metody wykładni prawa podatkowego nie odbiegają od procesu i metod właściwych innym gałęziom prawa, z tym jednak zastrzeżeniem, że w prawie podatkowym mamy do czynienia z ogromnymi mechanizmami prawno-ekonomiczno-finansowymi, które nazywamy podatkami. Ponoszenie przez podatnika ciężaru indywidualnej ofiary na zbiorowy cel odbywa się więc przy zastosowaniu skomplikowanego mechanizmu opisanego prawem, którego celem jest dokonanie przesunięć o charakterze pieniężnym. Jeśli dzięki analizie całości regulacji, które określają zasady działania tego mechanizmu (czyli ustawy podatkowej), można uzyskać szczegółowe informacje o jego strukturze, istocie i zasadach działania, to informacje te mogą zostać użyte w trakcie wykładni przepisu ustawy podatkowej w celu osiągnięcia takiego rezultatu wykładni, który najlepiej wpisuje się w ów podatkowy mechanizm. Sięganie do struktury ustawy podatkowej może być postrzegane jako element wykładni systemowej wewnętrznej, niemniej jednak już odwołanie się do stojących za tekstem prawnym mechanizmów ekonomiczno-finansowych, dalekie od ideałów pozytywizmu prawnego, niewątpliwie musi być rozważane szczególnie ostrożnie.

\section{KONTEKSTUALIZACJA KOHERENCYJNO-STRUKTURALNA}

Obecnie nauka prawa podatkowego nie dysponuje takim kompleksowym narzędziem, które pozwalałoby - w sposób usystematyzowany, a zarazem rygorystyczny i wpisujący się w ogólne zasady wykładni - na pogłębienie i poszerzenie wykładni systemowej i dawało oparcie umożliwiające odejście od rezultatów wykładni językowej, gdy dochodzi do wyraźnej kolizji pomiędzy otrzymanym rezultatem tej wykładni a sensem i duchem struktury podatku. Wielu autorów, ze wszystkich kręgów prawnych, podejmowało próby stworzenia podstaw umożliwiających w prawie podatkowym na odejście od językowego brzmienia przepisu. Przykładem może być praca L. Zelenaka dotycząca niedosłownej wykładni prawa podatkowego ${ }^{23}$, która wywarła wpływ na literaturę przedmiotu na przełomie tysiącleci. W krajowej literaturze prawa wskazuje się, opierając się m.in. na pracy przywołanego autora, na znaczenie zagadnienia struktury głębokiej prawa podatkowego i wykorzystanie cech tejże struktury jako argumentu

${ }^{23}$ L. Zelenak, Thinking about nonliteral interpretations of the Internal Revenue Code, „North Carolina Law Review” 1986, vol. 64, s. 623-676. 
interpretacyjnego ${ }^{24}$; do struktury głębokiej odwoływał się znacznie wcześniej, w 1976 r., C.I. Kingson, dając przyczynek do dalszej analizy tego podejścia ${ }^{25}$. Zauważa się także, że purystyczne podejście (ograniczone do analizy tekstu) jest bardzo zwodnicze i kompleksowa analiza regulacji prawnej przepisu prawa podatkowego, gdy tak wielki obszar tej gałęzi prawa wiąże się z zagadnieniami międzynarodowymi, jest nie tylko konieczna, ale i wymaga uwzględnienia w wykładni kontekstu politycznego, historycznego, socjologicznego oraz instytucjonalnego ${ }^{26}$. Przeprowadzenie takiej analizy przy użyciu dostępnych metod wykładni jest w zasadzie niemożliwe.

Historia rozwoju cywilizacji wskazuje, że w sytuacji gdy potrzebne jest dla usprawnienia określonego procesu nieistniejące narzędzie, prędzej czy później zostaje ono stworzone. Nie inaczej jest i w naukach prawnych. Można zaproponować, w charakterze takiego właśnie narzędzia, nową dyrektywę interpretacyjną, tj. dyrektywę kontekstualizacji koherencyjno-strukturalnej. Zasadniczo, w większości sytuacji, pełnić będzie ona rolę komplementarną względem wykładni językowej (czyli pomoże dokonać wyboru spośród możliwego sensu słów ich najtrafniejszego znaczenia), lecz jednocześnie przejmie prymat w sytuacji oczywistego konfliktu pomiędzy wynikami wykładni językowej a strukturą, istotą, duchem i zasadą działania konkretnego podatku. Można o kontekstualizacji koherencyjno-strukturalnej obrazowo myśleć jako o drugim pilocie, którego zadaniem jest wspierać kapitana (wykładnia językowa), ale który ma pewną szczególną umiejętność nieposiadaną przez kapitana, z którą wiąże się konieczność przejęcia sterów w niezwykłej sytuacji.

Dyrektywę kontekstualizacji koherencyjno-strukturalnej należy uznać za właściwą tylko prawu podatkowemu; jest ona w pewnym sensie swoistym mechanizmem hybrydowym ze względu na odnoszenie się do ustaleń o charakterze ekonomiczno-finansowym, aczkolwiek wydaje się w większym stopniu zasługiwać na określenie metody prawoznawstwa niż szeroko akceptowana ekonomiczna analiza prawa.

24 B. Brzeziński, Zasady wykładni prawa podatkowego $w$ krajach anglosaskich, Warszawa 2007, s. 89; idem, Wykładnia..., s. 100-101.

25 C.I. Kingson, The deep structure of taxation: Dividend distributions, „The Yale Law Journal" 1976/77, vol. 85, s. 861-913.

26 A. Cockfield, Purism and contextualism within international tax law analysis: How traditional analysis fails developing countries, „eJournal of Tax Research” 2007, no. 5, s. 199-224. 
Kontekstualizacja koherencyjno-strukturalna stanowi mechanizm złożony z (A) ograniczonej metody kontekstowej, (B) uproszczonej metody rozwiązywania problemu koherencyjnego oraz (C) zaimplementowanej wykładni systemowo-strukturalnej.

Część kontekstowa (A) omawianego pozajęzykowego podejścia do wykładni nakazuje określenie i rozważenie wszelkich istotnych dla wykładni przepisu prawa podatkowego kontekstów. W ich poszukiwaniu interpretatorowi wolno wyjść poza granice tekstu. Podejście to wywodzi się z metody kontekstowej znanej komparatystyce prawniczej, gdzie przeciwstawiane jest tekstualizmowi ${ }^{27}$. Natomiast potraktowanie zagadnienia wykładni w kategorii koherencyjnego problemu do rozwiązania (B) narzuca przyjęcie dogmatu, że spójność prawa nie jest tylko celem dla wykładni czy narzędziem argumentacyjnym, ale cechą zbioru elementów, który powstaje na skutek przeprowadzenia rozumowania przez interpretatora ${ }^{28}$. W sytuacji gdy w drodze wykładni otrzymujemy kilka konkurencyjnych wyników, traktujemy je jako zbiory desygnatów i analizujemy ich przynależność. W procesie tym zmierzamy do wybrania takiego zbioru, którego elementy utworzą bardziej spójną całość niż inne zbiory, tak względem siebie samych, jak i względem całej ustawy podatkowej. W kolejnym kroku (C) korzystamy z metody analizy strukturalnej, stanowiącej szeroko rozumianą metodę analizy systemowej, obejmującą swoim zakresem nie tylko analizę prawa i jego struktur, ale i analizę finansowo-ekonomiczną badanej regulacji, czyli przewidywalne skutki przesunięć pieniężnych, jakie w prawie podatkowym spowoduje przyjęcie konkretnego wariantu interpretacyjnego. Analizując struktury podatkowe zarówno analitycznie, jak i syntetycznie, można uzyskać obraz struktury całego podatku niewyrażonej bezpośrednio w przepisach prawa, co w przypadku konieczności dokonania wyboru spośród konkurencyjnych rezultatów wykładni, uzyskanych na skutek wcześniejszych działań, stanowić będzie wskazówkę interpretacyjną pozwalającą na dokonanie wyboru zbioru desygnatów najbardziej koherentnego z mechanizmem podatkowym opisanym ustawą.

27 Por. R. Tokarczyk, Komparatystyka prawnicza, Warszawa 2008, s. 74 i n. wraz z przywołaną tam literaturą.

28 Por. M. Araszkiewicz, Koherencyjny model rozumowań prawniczych, „Archiwum Filozofii Prawa i Filozofii Społecznej” 2010, nr 11, s. 26 wraz z przywołaną tam literaturą. 
Jak więc należy interpretować zasadę kumulacji przedmiotowo-podmiotowej, skoro rezultat wykładni zamknięty granicą językową, czyli sensem słów, prowadzi do absurdu? Można uznać, że zastosowanie kontekstualizacji koherencyjno-strukturalnej w procesie wykładni skutkuje rozwiązaniem wykraczającym poza granicę językową wykładni, ale zgodnym z głęboką strukturą ustawy podatkowej. Badając w tym konkretnym przypadku kontekst obowiązywania art. 9 ust. 2 u.p.s.d. (A), ustalamy, że zasada kumulacji w odniesieniu do podstawy opodatkowania, przy przysporzeniach nieodpłatnych, obecna jest w polskim prawie od ponad stu lat, w trakcie których zmieniło się otoczenie prawne i kontekst systemowy, a sama zasada uległa rozbudowaniu w drodze ewolucji. Przeprowadzenie wykładni językowej, nawet przy uwzględnieniu dyrektywy funkcjonalnej, prowadzi do uzyskania rezultatu (B), który można potraktować jako zbiór wewnętrznie spójny, możliwy do zastosowania (jak w analizowanym przykładzie dwóch darowizn), ale niekoherentny z mechanizmem podatkowym, tj. niepasujący do struktury głębokiej podatku i zaburzający jego poprawne działanie. Dopiero skorzystanie z przesłanek interpretacyjnych, jakich dostarcza wykładnia systemowo-strukturalna (C) (jak niewspółmierność, przy drugiej darowiźnie, kwoty powstającego zobowiązania podatkowego na skutek zastosowania kumulacji), pozwala uznać takie przesunięcie pieniężne za niezgodne z ustawą podatkową na skutek braku koherencji ze strukturami mechanizmu podatkowego. Skoro w zakresie granicy językowej brak jest takiego zbioru (takiego znaczenia słów), który byłby zgodny ze stawianymi warunkami, należy granicę tę złamać, ale tak, by odejście od rezultatu wykładni językowej było możliwie jak najmniejsze.

W celu uzyskania zgodności wykładni art. 9 ust. 2 u.p.s.d. z konstrukcją podatku (co udowodniono dla przedstawionego jako przykład stanu faktycznego) należy więc uznać, co jest konsekwencją przedstawionego rozumowania, że przy obliczeniu podstawy opodatkowania „dolicza się wartość rzeczy i praw majątkowych nabytych od tej osoby lub po tej samej osobie", ale z wyłączeniem wartości rzeczy i praw majątkowych nabytych od tej osoby lub po tej samej osobie, które korzystały ze zwolnienia od podatku na podstawie art. 4a u.p.s.d. 


\section{BIBLIOGRAFIA}

Araszkiewicz M., Koherencyjny model rozumowań prawniczych, „Archiwum Filozofii Prawa i Filozofii Społecznej” 2010, nr 11.

Brzeziński B., Wykładnia prawa podatkowego, Gdańsk 2013.

Brzeziński B., Zasady wykładni prawa podatkowego w krajach anglosaskich, Warszawa 2007.

Chustecka K., Krawczyk I., Kurasz M., Ustawa o podatku od spadków i darowizn. Komentarz, LEX/el. 2007.

Cockfield A., Purism and contextualism within international tax law analysis: How traditional analysis fails developing countries, „eJournal of Tax Research” 2007, no. 5.

Filipczyk H., Postulat pewności prawa w wykładni operatywnej prawa podatkowego, Warszawa 2013.

Kingson C.I., The deep structure of taxation: Dividend distributions, „The Yale Law Journal” 1976/77, vol. 85.

Kotowski A., Językowa granica wykładni a reguła stuszności. Glosa do postanowienia SN $z$ dnia 2 lutego 2012 r. (IV KK 273/11), „Przegląd Sądowy” 2010, nr 10.

Kurzac M., Unikanie opodatkowania a uchylanie się od opodatkowania, „Studia Prawno-Ekonomiczne" 2017, t. 105, cejsh.icm.edu.pl/cejsh/element/bwmeta1.element.desk light-b23d0373-f073-4e09-9926-b2e8c8c1a611/c/01_Kurzac.pdf (dostęp: 3.03.2018).

Mastalski R., Miejsce wykładni językowej w procesie stosowania prawa podatkowego, „Przegląd Podatkowy" 2007, nr 8.

Mastalski R., Wykładnia językowa w interpretacji prawa podatkowego, „Przegląd Podatkowy" 1999, nr 8.

Serwacki J., Ustawa o podatku od spadków i darowizn. Komentarz, LEX/el. 2001.

Spyra T., Granice wykładni prawa. Znaczenie jezzykowe tekstu prawnego jako granice wykładni, Kraków 2006.

Tokarczyk R., Komparatystyka prawnicza, Warszawa 2008.

Zelenak L., Thinking about nonliteral interpretations of the Internal Revenue Code, „North Carolina Law Review" 1986, vol. 64.

\section{THE PRINCIPLE OF CUMULATION IN THE INHERITANCE AND DONATION TAX - DEEP STRUCTURE VERSUS LANGUAGE LIMIT OF INTERPRETATION}

Summary. The principle of cumulation in the inheritance and donation tax, as a legal concept, is an institution with a hundred-year history. Due to law changes and changes in law structure, proper interpretation is very difficult. Obeying the literal interpretation border necessarily leads to an unacceptable result. The solution ensuring the proper functioning of the cumulation rule is to transgress the limits of linguistic interpretation, so that the result of the interpretation would be in accordance with the deep structure of the tax act. In breaking the language border, a specific method of law interpretation can be helpful, method thats taking into account contextualism as well as the coherence of law and the legal and economic structure.

Keywords: the principle of cumulation, language limits of interpretation, interpretation of tax law, inheritance and donation tax, coherence, deep structure 